\title{
MEASURING AN ORGANIZATION'S CHANGE READINESS REGARDING THE IMPLEMENTATION OF CORPORATE SOCIAL RESPONSIBILITY
}

\author{
iD Zineb Britel ${ }^{1+}$ \\ Abdelghani \\ Cherkaoui $^{2}$
}

\author{
${ }_{1,2}^{1,2}$ dustrial Engineering Department, Mohammadia School of Engineers \\ EMI, Mohammed V University, Morocco. \\ 'Email:britelzineb@gmail.com Tel:(212)666208890 \\ Email:cherkawi@emi.ac.ma Tel: (212)664986223
}

ABSTRACT

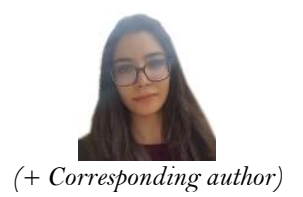

(+ Corresponding author)

\section{Article History}

Received: 22 November 202 Revised: 30 December 2021 Accepted: 14 January 2022 Published: 2 February 2022

\section{Keywords}

Readiness for change

Corporate social responsibility

Maturity model

Evaluation framework

Analytic hierarchy process

Fuzzy comprehensive evaluation

Delphi method.
To successfully implement corporate social responsibility within an organization, and to enhance proactive behaviors that support change, it is essential to ensure the members' readiness for change. However, the question that often arises is how an organization's level of change readiness can be measured. This paper describes the development of a change readiness evaluation framework based on a maturity model perspective that combines the Analytic Hierarchy Process with the Fuzzy Comprehensive Evaluation Method; the Delphi method is also used to reach consensus among the participants. This framework takes the relative importance of change readiness factors into consideration and provides detailed evaluation results for each category of factors. The uncertainty and subjectivity that is inherent in the human factor is also considered, and the maturity model approach helps to situate the organization's change readiness maturity level on a spectrum. The presented case study aims to assess a bank's readiness for change regarding the implementation of corporate social responsibility. The obtained results attest to an average change readiness maturity level and have several practical implications, such as the necessity of creating a targeted improvement roadmap in response to the evaluation results. Specifically, it revealed the necessity of enhancing the company's structural factors as well as undertaking further improvement efforts regarding change communication and change recipients' individual's attributes.

Contribution/Originality: This paper documents the development of a change readiness evaluation framework based on a review of the previous literature on the subject. The uncertainty of the human factor is considered through the application of a combined AHP-FCEM approach. This allows for the definition of the organization's change readiness maturity level and the creation of a targeted improvement roadmap based on the FCEM results.

\section{INTRODUCTION}

In the light of recent global developments, such as climate change, repetitive financial crises, the emergence of new technologies, the energy transition, evolving consumer demands, regulations, the growing interest manifested by investors, as well as pressure from stakeholders and non-governmental organizations, companies have been more and more inclined to adopt a Corporate Social Responsibility (CSR) approach.

According to the ISO 26000 standard, social responsibility refers to an organization's responsibility for the impacts of its decisions and activities on society and the environment, through transparent and ethical behavior. It translates the organization's contribution to sustainable development. In social responsibility approaches, stakeholders' expectations of communication, transparency and accountability are also taken into account. 
The role of change management in companies' strategic integration of CSR has been previously demonstrated in the literature. For instance, the importance of generating the required momentum to achieve organizational readiness for change, and the role it plays in enabling the integration of strategic CSR within organizations (Breitbarth \& Rieth, 2012). It has also been established that the degree to which a company has invested in internal change processes intended for the integration of CSR principles in the company's operations and strategies is a determinant for ensuring the manager's cognitive alignment with stakeholders with regard to their cognitive representations of CSR, as well as a better social performance of the company overall (Zollo et al., 2009).

The necessity of managing and adapting to an evolving environment and constant change has raised companies' awareness of the importance of ensuring their readiness for change. Organizations that display high levels of change readiness are often rewarded by employees' cooperativeness, sense of initiative and persistence (Weiner, 2009). Change readiness can also influence individual and organizational outcomes, such as change capabilities, performance, change supportive behaviors and positive attitudes (Rafferty, Jimmieson, \& Armenakis, 2013). The concept of change readiness is often considered a crucial factor in the implementation of effective and successful change (Halpern, Mwesiumo, Suau-Sanchez, Budd, \& Bråthen, 2021; Weiner, Clary, Klaman, Turner, \& Alishahi-Tabriz, 2020).

Since it is vital to assess a company's readiness for change prior to undertaking that change, the question that arises is how to measure the organization's readiness for change. This will allow the organization to be situated in its "as is" state of change readiness and help identify areas for improvement to attain the desired state "to be", whether for a specific change project or overall organizational readiness.

In this regard, this paper aims to provide a change readiness evaluation framework and apply it to a corporate social responsibility implementation case study within a bank. The research questions that will be addressed in the light of the proposed case study are the following:

- How can we measure an organization's readiness for change?

- How can we help identify improvement areas for better change readiness?

The contribution of this paper to the literature lies in the following aspects:

- Proposing an evaluation framework based on the conducted literature review on change readiness and experts' opinions, and the practical application of this framework in a case study.

- Addressing some of the limitations found in the literature, such as the need to refine measurement methods (Holt \& Vardaman, 2013) and providing an alternative to studies that feature the inherent bias of relying on retrospective employee reports (Cunningham et al., 2002; Rafferty et al., 2013) by employing an anticipatory approach.

- Taking into account the uncertainty and subjectivity of the respondents, especially since change management is centered on the human factor (Dievernich, 2015).

- Discussing the suitability of the application of the proposed evaluation framework (Analytic Hierarchy Process, Fuzzy comprehensive evaluation, Delphi method, maturity model perspective).

- Discussing the managerial implications that stem from the use of the proposed approach, such as the ability to identify the change readiness level of an organization through a maturity-based approach, and the definition of a targeted improvement roadmap. The proposed methodology also has the potential to be applied in similar studies.

The structure of the paper is as follows: Section two provides a review of the literature on the concepts of corporate social responsibility and readiness for change. The proposed methodology for the construction of the evaluation framework is described in section three. Its application to the case study of a change readiness evaluation for the implementation of corporate social responsibility within a bank is presented in section four. The obtained results are presented in section five, and then analyzed and discussed in section six, before the conclusions are provided in section seven. 


\section{LITERATURE REVIEW}

This section presents a review of the concepts of corporate social responsibility and readiness for change, as well as a brief overview of prior change readiness evaluation tools and methodologies. Different change readiness factors extracted from the literature review are explored and serve as a basis for the construction of the proposed model for change readiness evaluation.

\subsection{Corporate Social Responsibility}

The concept of Social Responsibility was introduced by Bowen (1953). Originally, it referred to the moral imperative of businessmen to consider society's goals and values in their decision-making process and company conduct. Over time, according to Patrick Murphy's analysis (Murphy, 1978), this concept has evolved from pre-1953 "philanthropic activities", to the recognition of businesses' responsibility and involvement in community affairs during an "awareness era" (1953-1967). Following this, companies started to focus on specific issues such as pollution, racial discrimination, and others, in the so-called "issue era" (1968-1973). Finally, in the "responsiveness era" and beyond, organizational and managerial actions are taken by companies to address CSR issues. Since the 1990s, there is a growing interest in the literature in the combination of CSR with business strategy, as it is considered an integral factor in a company's strategy and success (Carroll, 2008; Kotler \& Lee, 2005; Kramer \& Porter, 2011).

Engaging in a CSR approach encourages shared value creation (Jonikas, 2012). Companies are no longer expected to be evaluated solely on their economic performance, but also on their commitment to the environment and the welfare of society, thus increasing their contributions to social equity, better organizational governance, and healthier ecosystems. In return, companies benefit from better relationships with stakeholders (suppliers, competitors, customers, governments, the media, etc.) (Kang, Chiang, Huangthanapan, \& Downing, 2015; Yin \& Jamali, 2016), a better reputation in the eyes of customers, investors, sponsors, etc., increased retention of talents and the ability to maintain employee morale, commitment, productivity, and a competitive advantage (Saeidi, Sofian, Saeidi, Saeidi, \& Saaeidi, 2015) through the promotion of innovation (Reverte, Gomez-Melero, \& Cegarra-Navarro, 2016) by developing socially or environmentally friendly products or services and preventing and controlling environmental, social and governance-related risks .

CSR approaches can prove to be challenging due to a variety of factors, such as the multidimensional nature of the subject, the contested nature of the concept (Gond \& Igalens, 2008) and the lack of credibility and skepticism towards similar approaches that are considered to be a façade intended to improve the company's image or to silence critics. Another challenge lies in ensuring the sustainability of the approach, as significant time is needed to change behaviors.

To meet these challenges, efforts should be made in two directions: clearly defining the CSR priorities to be addressed and instilling and embedding CSR in daily behavior, as well as defining a structured CSR approach to create a credible CSR commitment.

\subsection{The Concept of Change Readiness}

Readiness for change is often considered a multilevel construct, relevant at different levels of analysis (the individual, group, and organizational levels) (Holt, Helfrich, Hall, \& Weiner, 2010; Rafferty et al., 2013; Vakola, 2013; Weiner, 2009). This has led to a variety of definitions across the literature. Considering the individual perspective, Armenakis, Harris and Mossholder define change readiness as an individual's "beliefs, attitudes, and intentions regarding the extent to which changes are needed and the organization's capacity to successfully undertake those changes" (Armenakis, Harris, \& Mossholder, 1993). In this definition, change readiness is thus presented as a proactive approach rather than a reactive monitoring of resistance signals. Other definitions define change readiness as the extent to which the people involved are "individually and collectively primed, motivated, and technically capable of executing the change" (Holt et al., 2010). In the proposed framework, both individual and organizational factors of 
change readiness were considered, since considering the individual factors alone may be insufficient as this would disregard the influence of the social sphere (Dievernich, 2015). Readiness for change can be categorized into two types: the first defined by the psychological approach (Armenakis et al., 1993) and the second defined by a structural approach that focuses on capabilities and resources (Weiner, Amick, \& Lee, 2008). Both the psychological aspect inherent in the human factor, as well as the capabilities approach were considered in the developed framework.

\subsection{Change Readiness Evaluation Tools}

Several literature reviews have addressed the concept of change readiness and reviewed the existing measures of organizational change readiness (Gagnon et al., 2014; Weiner et al., 2008; Weiner et al., 2020). All these reviews have noted that several of the readiness assessment tools offer only limited reliability and validity. The existing measures also appear to have different goals, such as readiness description, adoption and implementation prediction, studies of change-related attitudes, and the prediction of other outcomes like employee turnover and job satisfaction. The aim of the present study covers the three first categories, it will help answer the questions: How ready is the company for change? Which factors should be addressed to improve change-related attitudes and capabilities?

According to a recent review by Weiner et al. (2020), change readiness assessment tools have been used in different fields, such as business, healthcare and non-for-profit domains. However, few readiness tools allow both the individual and organizational levels of readiness to be measured (only 7\%). The proposed readiness model comprises both key dimensions, as suggested by Holt \& Vardaman that presented the key dimensions of individual difference factors and Structural ones, at two levels of analysis: the individual and the organizational (Holt \& Vardaman, 2013). Another perspective on change readiness has been proposed by Combe, who considered three main drivers of change readiness: Capacity, Commitment and Culture (Combe, 2014).

According to the review by Weiner et al. (2020), the most widespread readiness tools are the "Texas Christian University Organizational Readiness for Change" (TCU-ORC) (Lehman, Greener, \& Simpson, 2002) the "Individual Readiness for Organizational Change" (IROC) (Holt, Armenakis, Feild, \& Harris, 2007), and the "Organizational Readiness to Change Assessment" (ORCA) (Helfrich, Li, Sharp, \& Sales, 2009) with two of these tools being quite lengthy (ORCA: 19 scales and 77 items, TCU-ORC: 18 scales and 118 items). It is also interesting to note that some instruments that offer promising psychometric properties are the Organizational Readiness for Implementing Change (Shea, Jacobs, Esserman, Bruce, \& Weiner, 2014) the Perceived Organizational Readiness for Change (Cinite, Duxbury, \& Higgins, 2009), the Organizational Change Recipients Beliefs Scale (Armenakis, Bernerth, Pitts, \& Walker, 2007), and the Organizational Change Questionnaire-Climate of Change, Processes, and Readiness (OCQC, P, R) by Bouckenooghe (Bouckenooghe, Devos, \& Van den Broeck, 2009). Aside from these scale-based tools, there are also some quite different evaluation approaches, such as Stevens's process-based approach (Stevens, 2013). Other change readiness studies have focused on the change message and the factors within it that lead to readiness (Armenakis and Stanley (2002); Bernerth (2004)). Therefore, a full category has been dedicated to this in the proposed model. The originality of the proposed evaluation framework, in contrast with the existing tools, lies in the consideration of the uncertainty and imprecision inherent in the human factor, combined with a maturity evaluation that is practical for decision-making in a managerial context.

\subsection{Change Readiness Factors}

To build a change readiness evaluation framework, it is essential to first identify the relevant change readiness factors. The table below summarizes the relevant literature on which the proposed framework is based. 
Table 1. The proposed framework justifications.

\begin{tabular}{|c|c|c|}
\hline Category description & Sub factors description & Justification \\
\hline $\begin{array}{l}\text { Change context: } \\
\text { The organizational } \\
\text { context of the planned } \\
\text { change }\end{array}$ & $\begin{array}{l}\text { - Organizational politics: The perceived level of } \\
\text { political games within the organization } \\
\text { (Weiner, 2009) } \\
\text { - Past experience: Positive or negative } \\
\text { experience with change (Weiner, 2009) } \\
\text { - Policies and procedures: Existing company } \\
\text { policies and procedures (Weiner, 2009) } \\
\text { - Environment and organizational climate: The } \\
\text { organizational culture of the company (Weiner, } \\
\text { 2009) } \\
\text { Cohesion: The perception of togetherness, } \\
\text { cooperation and sharing (Bouckenooghe et al., } \\
\text { 2009) } \\
\text { Discrepancy: A sense of urgency or the need for } \\
\text { change, the realization that there are legitimate } \\
\text { reasons for the change (Holt et al., 2007) }\end{array}$ & $\begin{array}{l}\text { We maintained Weiner's } \\
\text { placements of } \\
\text { organizational politics, } \\
\text { policies and procedures, } \\
\text { organizational culture and } \\
\text { past experience within } \\
\text { contextual factors } \\
\text { (Weiner, 2009). Cohesion } \\
\text { is added to the context } \\
\text { factors as proposed by } \\
\text { (Bouckenooghe et al., } \\
\text { 2009) and discrepancy is } \\
\text { placed within the internal } \\
\text { change context category } \\
\text { as proposed by Holt et al. } \\
\text { (2007). }\end{array}$ \\
\hline $\begin{array}{l}\text { Change content: } \\
\text { The content of the } \\
\text { planned change }\end{array}$ & $\begin{array}{l}\text { - Organizational valence: The realization of the } \\
\text { change's benefits to the organization. } \\
\text { - Appropriateness of the change: The planned } \\
\text { change is well suited to the organization. }\end{array}$ & $\begin{array}{l}\text { The two factors are } \\
\text { supported by Holt et al. } \\
(2007)\end{array}$ \\
\hline $\begin{array}{l}\text { Structural factors: The } \\
\text { availability of necessary } \\
\text { structure, resources and } \\
\text { workers' knowledge, } \\
\text { skills, and the alignment } \\
\text { of their abilities with the } \\
\text { change }\end{array}$ & $\begin{array}{l}\text { - Knowledge, skills, ability alignment (Holt \& } \\
\text { Vardaman, 2013) are also present in the people } \\
\text { category (Combe, 2014) } \\
\text { Organizational resources and structure } \\
\text { (Weiner et al., 2008), extended to include other } \\
\text { elements, such as processes, technology/ } \\
\text { support resources, physical resources and } \\
\text { organizational systems (Combe, 2014). }\end{array}$ & $\begin{array}{l}\text { Holt and Vardaman } \\
(2013) \text { place knowledge, } \\
\text { skills and ability alignment } \\
\text { within the structural } \\
\text { factors (Holt \& Vardaman, } \\
\text { 2013). We include the } \\
\text { organizational resources } \\
\text { and structure inspired by } \\
\text { the capacity assessment. }\end{array}$ \\
\hline $\begin{array}{l}\text { Change process readiness: } \\
\text { The process of } \\
\text { implementation of the } \\
\text { change (Bouckenooghe et } \\
\text { al., 2009) }\end{array}$ & $\begin{array}{l}\text { - Management support: The support and } \\
\text { understanding provided by immediate } \\
\text { supervisors to employees (Bouckenooghe et al., } \\
\text { 2009; Holt et al., 2007) } \\
\text { - Attitudes of top management: The position of } \\
\text { top management towards the change } \\
\text { (Bouckenooghe et al., 2009) } \\
\text { - Participation: The involvement of employees in } \\
\text { the change and keeping them informed of } \\
\text { decisions that affect them (Bouckenooghe et al., } \\
\text { 2009). }\end{array}$ & $\begin{array}{l}\text { Bouckenooghe et al. (2009) } \\
\text { place quality of change } \\
\text { communication in the } \\
\text { process category } \\
\text { (Bouckenooghe et al., } \\
\text { 2009); however, we placed } \\
\text { this factor in a dedicated } \\
\text { change communication } \\
\text { readiness category. }\end{array}$ \\
\hline communication & $\begin{array}{l}\text { Communication on: } \\
\text { - Discrepancy: Communication on the necessity } \\
\text { of change } \\
\text { - Efficacy: Communication on the confidence in } \\
\text { employees' abilities to implement the change } \\
\text { - Appropriateness of the change: Communication } \\
\text { on the change's accuracy in responding to the } \\
\text { discrepancy identified. } \\
\text { - Principal support: Communication on the } \\
\text { support of leaders. } \\
\text { - Valence: Communication on the benefits of } \\
\text { change. } \\
\text { Quality of change communication: The way the } \\
\text { change is communicated and its effectiveness } \\
\text { (clarity, frequency and } \\
\text { (Bouckenooghe et al., 2009) }\end{array}$ & $\begin{array}{l}\text { Armenakis et al. (1993) } \\
\text { support the first five } \\
\text { message components } \\
\text { (Armenakis \& Stanley, } \\
\text { 2002; Bernerth, 2004). }\end{array}$ \\
\hline
\end{tabular}




\begin{tabular}{|c|c|c|}
\hline Category description & Sub factors description & Justification \\
\hline $\begin{array}{l}\text { Change agent attributes: } \\
\text { The change agents are the } \\
\text { individuals that lead the } \\
\text { change within the } \\
\text { organization }\end{array}$ & $\begin{array}{l}\text { - Perceived credibility: The credibility of a } \\
\text { message source with no regard to the content. } \\
\text { - Trustworthiness: The ability to be relied on as } \\
\text { honest or truthful (Oxford Dictionary). } \\
\text { - Sincerity: The absence of pretense, deceit or } \\
\text { hypocrisy (Oxford Dictionary). } \\
\text { - Expertise: Both content expertise regarding } \\
\text { the change and change process expertise } \\
\text { (Backer, 1995). }\end{array}$ & $\begin{array}{l}\text { The factors are supported } \\
\text { by Turner (1982). } \\
\text { Armenakis and } \\
\text { Fredenberger (1997) insist } \\
\text { on employees' confidence } \\
\text { in change agents' expertise } \\
\text { (Armenakis } \\
\text { Fredenberger, 1997). }\end{array}$ \\
\hline $\begin{array}{l}\text { Change recipient's } \\
\text { individual factors }\end{array}$ & $\begin{array}{l}\text { - Values: Principles or standards of behavior } \\
\text { (Oxford Dictionary). } \\
\text { - Self-efficacy: An individual's confidence in their } \\
\text { own ability to perform the change. } \\
\text { - Yield - Personal valence: The benefits or } \\
\text { rewards that may result from the change. }\end{array}$ & $\begin{array}{l}\text { Baker supports values } \\
\text { (Backer, 1995). Self- } \\
\text { efficacy and yield are } \\
\text { considered important } \\
\text { individual change } \\
\text { readiness attributes by } \\
\text { Holt et al. (2007). }\end{array}$ \\
\hline $\begin{array}{l}\text { Change recipient's } \\
\text { organizational factors }\end{array}$ & $\begin{array}{l}\text { - Vision for change: The construction of a vision } \\
\text { of what the change is, why, and how to achieve } \\
\text { it (Kotter, 2007; Smith, 2005) } \\
\text { - Organizational commitment: The dedication } \\
\text { and belief in the organization's goals and values } \\
\text { (identification, involvement and loyalty) (Holt } \\
\text { \& Vardaman, 2013; Weiner, 2009) } \\
\text { Trust in leadership: The perceived trust of } \\
\text { employees in their supervisors and top } \\
\text { management (Bouckenooghe et al., 2009; Holt } \\
\text { \& Vardaman, 2013) } \\
\text { Collective efficacy: A group's confidence in its } \\
\text { own ability to perform the change (Backer, } \\
\text { 1995; Holt \& Vardaman, 2013; Weiner, 2009). } \\
\text { Social relationships: Work relationships } \\
\text { between employees: peers, supervisors, } \\
\text { subordinates (feelings, attitudes, perceptions, } \\
\text { etc.). }\end{array}$ & $\begin{array}{l}\text { Bouckenooghe et al. (2009) } \\
\text { place trust in leadership } \\
\text { within the context factors } \\
\text { (Bouckenooghe et al., } \\
\text { 2009). We placed it within } \\
\text { the collective attributes as } \\
\text { suggested by Holt and } \\
\text { Vardaman (2013) where it } \\
\text { is called collective trust. } \\
\text { Also, Madsen et al.'s study } \\
\text { shows a relationship } \\
\text { between change readiness } \\
\text { and social relationships } \\
\text { (Madsen, Miller, \& John, } \\
\text { 2005). }\end{array}$ \\
\hline
\end{tabular}

\section{METHODOLOGY}

The proposed methodology for a change readiness maturity evaluation model is described in the flowchart displayed in Figure 1.

\subsection{Conception of a Change Readiness Model}

After reviewing existing change readiness frameworks and factors, we developed the change readiness model in Figure 2 through a focus group with three change management experts with more than ten years of experience in managing change initiatives. The model is a hierarchical description of the change readiness evaluation criteria. Table 1 contains the definitions of the factors, the supporting studies and the model structure justifications.

\subsection{The Analytic Hierarchy Process}

The Analytic Hierarchy Process is a methodology that was developed by Saaty (1990). It is used to determine the relative importance of criteria and helps to decide between different alternatives. It is based on the construction of a hierarchy, the Evaluation Index System (EIS), to simplify the complexity of a problem. The hierarchy developed in this study is displayed in Figure 2. The method also requires the construction of judgement matrices based on the knowledge and opinions of experts, using pair wise comparisons according to Saaty's scale provided in Table 2 and relying on consistency tests. 
The choice of the AHP method for criteria weighting achieves a balance between chance of bias and complexity of the method. Despite the reduced potential for bias of more complex methods, they remain more resource-intensive and require increased participation efforts from the decisionmakers (Hujainah, Bakar, Abdulgabber, \& Zamli, 2018; Németh et al., 2019).

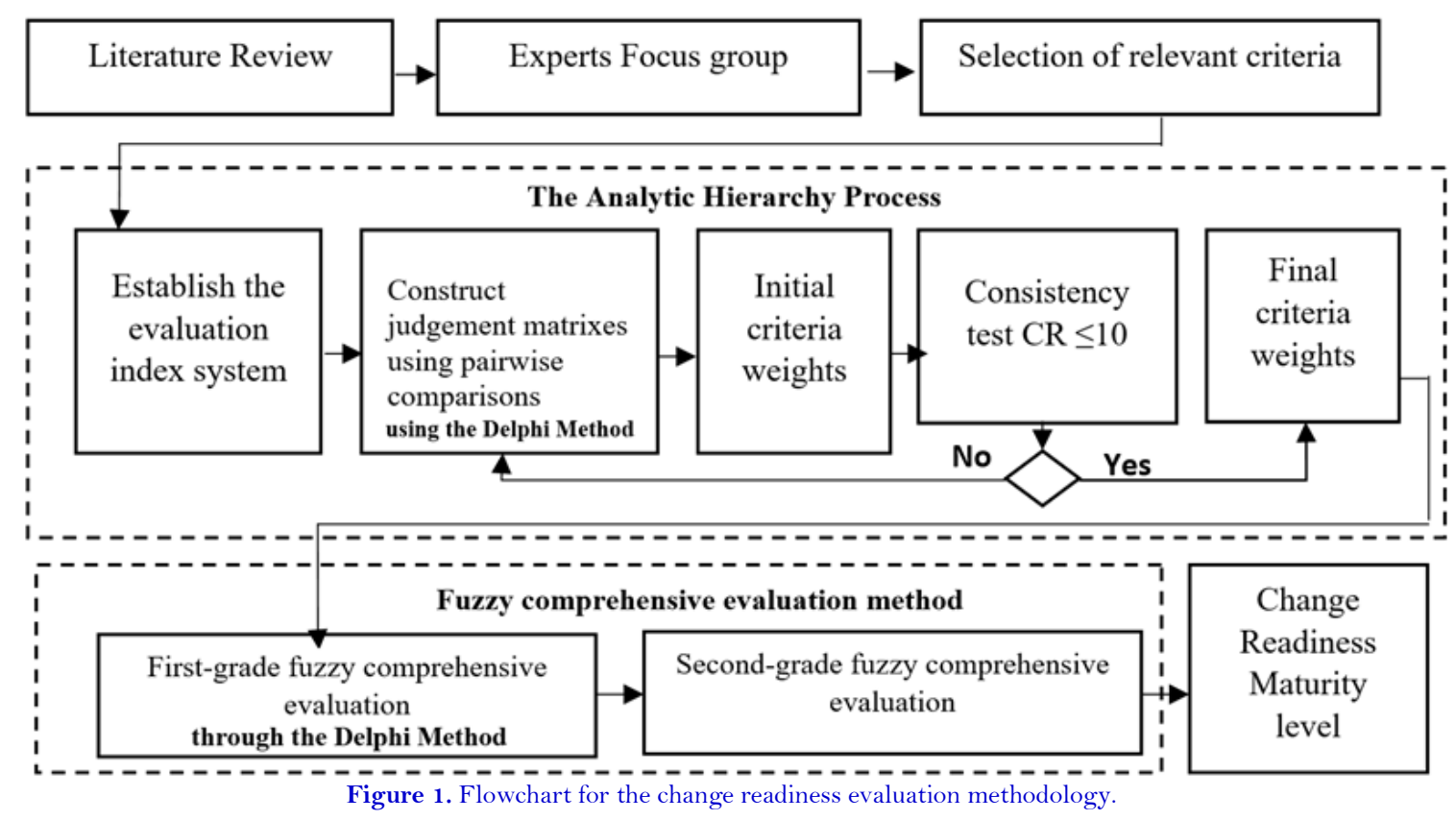

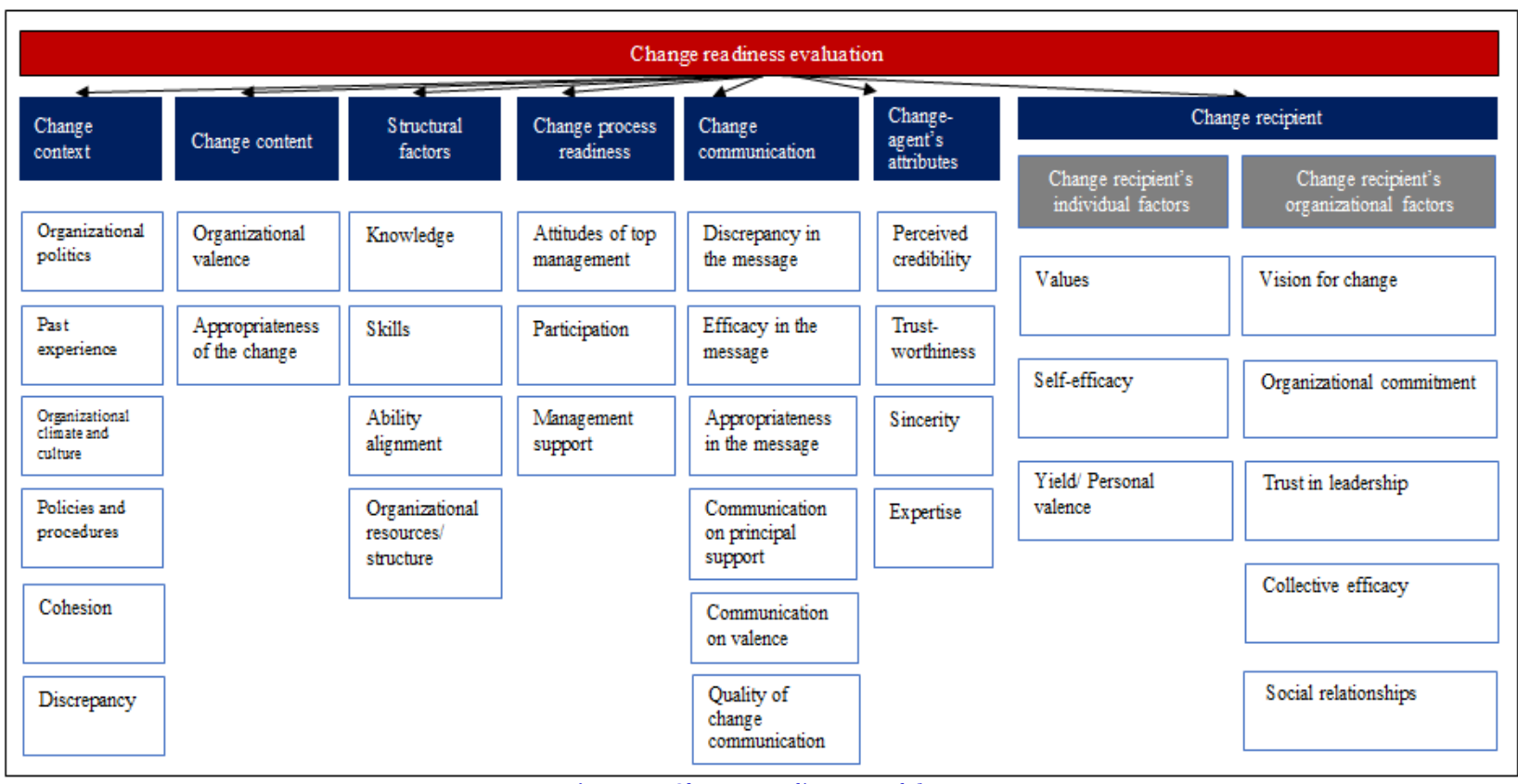

Figure 2. Change readiness model.

Table 2. L. Saaty's scale for pairwise comparisons.

\begin{tabular}{c|l}
\hline Intensity of importance & Definition \\
\hline 1 & Equal importance \\
\hline 3 & Moderate importance \\
\hline 5 & Strong importance \\
\hline 7 & Very strong importance \\
\hline 9 & Extreme importance \\
\hline $2,4,6,8$ & Intermediate values \\
\hline
\end{tabular}


The pairwise comparison matrices are expressed in Equation 1:

With: $\mathrm{a}_{\mathrm{ij}}$ the relative importance of element $\mathrm{i}$ to $\mathrm{j} ; \mathrm{a}_{\mathrm{ij}}>0 ; \mathrm{a}_{\mathrm{ij}}=1 / \mathrm{a}_{\mathrm{ji}} ; \mathrm{a}_{\mathrm{ii}}=1$.

$\mathrm{A}=\left(\mathrm{a}_{\mathrm{ij}}\right)_{\mathrm{nxn}}=\left[\begin{array}{ccc}a 11 & \cdots & a 1 n \\ \vdots & \ddots & \vdots \\ a n 1 & \cdots & \text { ann }\end{array}\right]$

To determine criteria weights, we solve Equation 2:

$\mathrm{AW}=\lambda_{\max } \mathrm{W}$

In which $\lambda_{\max }$ is the principal eigenvalue of $\mathrm{A}$, and $\mathrm{W}$ the associated normalized eigenvector, comprising the criteria weights.

To test the consistency of the matrixes, we calculate two ratios: the consistency index (CI), using Equation 3, and the consistency ratio (CR), using Equation 4, in which $\mathrm{n}$ is the matrix order and (RI) the random index listed in Table 3 .

$\mathrm{CI}=(\lambda \max -n) /(n-1)$
$\mathrm{CR}=\mathrm{CI} / \mathrm{RI}$

Table 3. Random index table.

\begin{tabular}{c|c|c|c|c|c|c|c|c|c|c}
\hline $\mathbf{n}$ & $\mathbf{1}$ & $\mathbf{2}$ & $\mathbf{3}$ & $\mathbf{4}$ & $\mathbf{5}$ & $\mathbf{6}$ & $\mathbf{7}$ & $\mathbf{8}$ & $\mathbf{9}$ & $\mathbf{1 0}$ \\
\hline $\mathrm{RI}$ & 0 & 0 & 0.58 & 0.9 & 1.12 & 1.24 & 1.32 & 1.41 & 1.45 & 1.49 \\
\hline
\end{tabular}

If the CR is less than 0.10 , the matrix is reasonably consistent, otherwise the preferences must be reviewed. Relying on this procedure, we calculate all the criteria weights.

\subsection{The Fuzzy Comprehensive Evaluation Method}

The fuzzy comprehensive evaluation method is a calculation method based on fuzzy mathematics. It helps transform a qualitative evaluation into a quantitative one using the membership degree theory of fuzzy mathematics. This method is particularly useful for complex problems that are difficult to express through precise mathematical techniques. It is used to assess fuzziness and uncertainty and provides support for decision-making (Zhu \& Dewancker, 2021). This study uses the fuzzy comprehensive evaluation method to evaluate a bank's readiness for the implementation of a corporate social responsibility approach. The use of the fuzzy comprehensive evaluation method (FCEM) is subsequent to the assignment of weights to the criteria using AHP.

Based on the EIS, with $U_{k}$ denoting the indexes of its second level, we consider $U=\left\{U_{k} ; k=1, \ldots, n\right\}$ a factor set, with $n$ : the number of second level criteria in the EIS. And $U k=\left\{U_{k i} ; k=1, \ldots, m\right\}$ with $m$ : the number of sub-indexes of $U_{k}$ (each index of the second level $U_{k}$ contains many sub-indexes of the third level).

We define the evaluation set as in Table 4, with the validation of experts $V=\left\{V_{1}, V_{2}, V_{3}, V_{4}, V_{5}\right\}$. This will be useful when conducting the evaluation by asking the participants to rate a specific factor or subfactor according to the proposed scale: Very Bad (VB), Bad (B), Medium (M), Good (G) and Excellent (E).

These components will form the model's five maturity levels.

We define the fuzzy vector $R_{i}=\left(r_{i 1}, r_{i 2}, \ldots, r_{i n}\right)$ with $i=1, \ldots, m$, based on the experts' evaluation of each index $U_{k}$.

The fuzzy comprehensive evaluation matrix, in Equation 5, is composed of a set of the vectors $\mathrm{R}_{\mathrm{i}}$. It represents the fuzzy relationship between the set of the sub-indexes of $\mathrm{U}_{\mathrm{k}}$ and the evaluation set $\mathrm{V}$.

$$
\mathrm{R}=\left[\begin{array}{ccc}
r 11 & \cdots & r 1 n \\
\vdots & \ddots & \vdots \\
r m 1 & \cdots & r m n
\end{array}\right]=\left(\begin{array}{c}
R 1 \\
R 2 \\
\vdots \\
R m
\end{array}\right)
$$

in which $r_{i j}$ is the membership score of the index $U_{k i}$ regarding the element $V_{j}$ of the evaluation set. 
Table 4. Evaluation set.

\begin{tabular}{l|l|c|l|l}
\hline Item & $\begin{array}{l}\text { Qualitative } \\
\text { value }\end{array}$ & $\begin{array}{l}\text { Numerical } \\
\text { value }\end{array}$ & $\begin{array}{l}\text { Corresponding maturity } \\
\text { level }\end{array}$ & Definition of the maturity level \\
\hline $\mathrm{V}_{1}$ & Very Bad $(\mathrm{VB})$ & 20 & No readiness for change & The organization is not ready for change. \\
\hline $\mathrm{V}_{2}$ & Bad $(\mathrm{B})$ & 40 & Low readiness for change & $\begin{array}{l}\text { The organization displays insufficient } \\
\text { readiness for change. }\end{array}$ \\
\hline $\mathrm{V}_{3}$ & Medium $(\mathrm{M})$ & 60 & Average readiness for change & $\begin{array}{l}\text { The organization has basic readiness for } \\
\text { change. }\end{array}$ \\
\hline $\mathrm{V}_{4}$ & Good $(\mathrm{G})$ & 80 & Good readiness for change & $\begin{array}{l}\text { The organization displays good readiness } \\
\text { for change. }\end{array}$ \\
\hline $\mathrm{V}_{5}$ & Excellent $(\mathrm{E})$ & 100 & Excellent readiness for change & $\begin{array}{l}\text { The organization displays excellent } \\
\text { readiness for change. }\end{array}$ \\
\hline
\end{tabular}

Supposing we have p experts, each expert evaluates all the elements, and we obtain the fuzzy evaluation membership matrix from Equation 6:

$\sum_{j=1}^{n} l i j=p \mathrm{R}_{\mathrm{i}}=\left(\mathrm{l}_{11} / \mathrm{p}, \ldots, \mathrm{l}_{\mathrm{i} 1} / \mathrm{p}\right)=\left(\mathrm{v}_{\mathrm{i} 1}, \ldots, \mathrm{vin}_{\mathrm{in}}\right)$

We conduct a first-grade fuzzy comprehensive evaluation ( $\mathrm{i}=1$ to $\mathrm{n}$ ) using Equation 7:

$\mathrm{B}_{\mathrm{i}}=\mathrm{W}_{\mathrm{i}} * \mathrm{R}_{\mathrm{i}}$

in which $\mathrm{R}_{\mathrm{i}}$ is the fuzzy evaluation membership matrix; $\mathrm{W}_{\mathrm{i}}$ the corresponding weights vector.

Followed by a second-grade fuzzy comprehensive evaluation, using Equation 8:

$\mathrm{B}=\mathrm{W}^{*}\left[\mathrm{~B}_{1}, \ldots, \mathrm{B}_{\mathrm{n}}\right]$

in which $\mathrm{W}$ is the weight vector of the secondary level; Bi the result of the first-grade fuzzy comprehensive evaluation.

Hence, the final evaluation is calculated as in Equation 9:

$\mathrm{S}=\mathrm{B} * \mathrm{~V}$

\subsection{The Delphi Method}

To construct the pairwise comparison matrices and to conduct the first-grade fuzzy comprehensive evaluation, it is important to achieve a consensus between the participants; therefore, a two-round Delphi methodology was used. The Delphi methodology is well known for structuring the communication process within a group of experts to obtain a consensus concerning a complex problem. It relies on feedback reports given back to experts to provide them with the opportunity to improve their opinions based on the received feedback (Dalkey \& Helmer, 1963)

Therefore, two rounds of questioning were conducted:

- In the first round, separate consultation interviews were organized with the participants. After this first round, the collected data was synthetized and analyzed (identification of extreme values, major differences, etc.). The obtained results were then returned to the experts with the opportunity to either justify and maintain their values or refine their propositions. This first round led to initial improved pairwise comparison matrices and an improved first fuzzy comprehensive evaluation.

- In the second round of the Delphi methodology, we emailed the improved matrices and evaluation table from the first round to the experts, asking them to insert their opinions or improvements for each element we obtained the final matrices and first-grade fuzzy comprehensive evaluation thanks to the compromises that some experts made following the feedback they received in the previous round.

For the purpose of providing concise results, only the final matrices resulting from the Delphi methodology are presented in the results section.

\subsection{The Change Readiness Maturity Model}

Maturity models represent progress and evolution in a specific domain across levels through measurable transitions, they are usually used for benchmarking or developing improvement roadmaps. The choice to rely on a maturity model perspective was made because it provides results in a form that is easily interpretable in a managerial 
context and helps quantify change readiness by providing the organization with a change readiness maturity level. It also enlightens the company on the areas to address to achieve a higher maturity level. The components of a maturity model are maturity levels, model domains, attributes, scoring methods and improvement roadmaps. The chosen maturity levels, representing the transitional states of the model, are presented in Table 4. As we transition from low levels of readiness to higher ones, it entails improved change capabilities and change supportive behaviors. The model domains (knowledge areas) and attributes are based on the conducted literature review in Table 1, and are presented in Figure 2. As for the chosen appraisal and scoring method for the assessment, we propose a combination of AHP for criteria weighting, and FCEM for scoring. Once the scoring is complete, improvement areas are identified and are the subject of an improvement roadmap. This model's scope is the assessment of change readiness regarding a specific change in an organizational context. It is intended to help executives and managers with decision-making while undertaking a change. We have simplified the maturity model to allow self-assessment without external support. The respondents should be composed of different representatives of all the parties affected by the change (employees, management, business partners, etc.).

\section{CASE STUDY: CHANGE READINESS EVALUATION FOR THE IMPLEMENTATION OF CORPORATE SOCIAL RESPONSIBILITY WITHIN A BANK}

Banks can play a central role in achieving a sustainable, positive and inclusive economy. Their engagement can be expressed through investment, financing and management decisions based on environmental, social and governance considerations, such as socially responsible investments, adoption of international CSR-related commitments, and consideration of extra-financial criteria in the financing of projects, as well as through the management of their internal affairs: social policies, relations with the different stakeholders (internal and external).

Our study thus aims to assess the change readiness of a Moroccan bank towards the adoption of a corporate social responsibility approach. Since its adoption of a new strategic plan, the bank has expressed its ambition to strengthen its social responsibility, with the aim of consolidating and anchoring the Bank's CSR policy by capitalizing on the progress made and aligning with the best practices in the banking sector.

The bank's objectives in adopting a corporate social responsibility approach are the following:

- The implementation of a structured approach that allows the bank to identify the relevant CSR issues for the bank and its stakeholders.

- Elaboration of a credible CSR policy that is coherent with the bank's stakeholders' expectations and implementing it throughout the organization.

- Defining appropriate communication and reporting modes.

\subsection{Study Design}

In order to evaluate a bank's readiness for change for the implementation of corporate social responsibility, a focus group was conducted by gathering the company's Change Management and Project teams. It was composed of the team members listed in Table 5, who are considered experts in their respective fields within the company and all have at least 8 years of experience managing large transversal projects within the bank.

The session started by defining Corporate Social Responsibility and the project's scope and goals. Then, after explaining the planned methodology with the proposed evaluation framework, empty pairwise comparison matrices were given to the participants, as well as empty fuzzy comprehensive evaluation tables. The pairwise comparison matrices were then constructed (based on the individual ones, using the Delphi method) and the evaluation was completed (also using the Delphi method). The results presented in the following section as well as the matrices available in the appendix reflect the consensus of the participants. 
Table 5. Focus group composition.

\begin{tabular}{l|c}
\hline Function & Number of participants \\
\hline Change management team & 3 \\
\hline CSR Project manager & 1 \\
\hline CSR Project manager assistant & 2 \\
\hline Communication team member & 1 \\
\hline Finance department managers & 3 \\
\hline Human resource managers & 2 \\
\hline Construction and reliability managers & 2 \\
\hline Quality, Security and Environmental manager & 1 \\
\hline
\end{tabular}

\section{RESULTS}

This section contains the results of the application of our AHP- FCEM change readiness maturity model. Using the AHP (Appendix A), we obtain the criteria weights in Table 6.

The first-grade fuzzy comprehensive evaluation results are presented in Table 7. These allow a first interpretation of the group's change readiness maturity, according to the defined levels in Table 4.

The second-grade fuzzy comprehensive evaluation is based on the results of the first-grade evaluation and is as follows, with $\mathrm{W}$ the weight vector of the first level of the group of criteria.

$\mathrm{B}=\mathrm{W} .\left[\mathrm{B}_{1}, \mathrm{~B}_{2}, \mathrm{~B}_{3}, \mathrm{~B}_{4}, \mathrm{~B}_{5}, \mathrm{~B}_{6}, \mathrm{~B}_{7}, \mathrm{~B}_{8}\right]$

$$
=\left[\begin{array}{lllll}
0.2023262 & 0.35439096 & 0.30271588 & 0.10927804 & 0.03078732
\end{array}\right]
$$

The final evaluation is obtained using equation 9:

$\mathrm{S}=\mathrm{B} * \mathrm{~V}=71.7337$

This result shows that the organization's readiness for the implementation of CSR is above average, but still needs some improvements to be good (as illustrated in Figure 3).

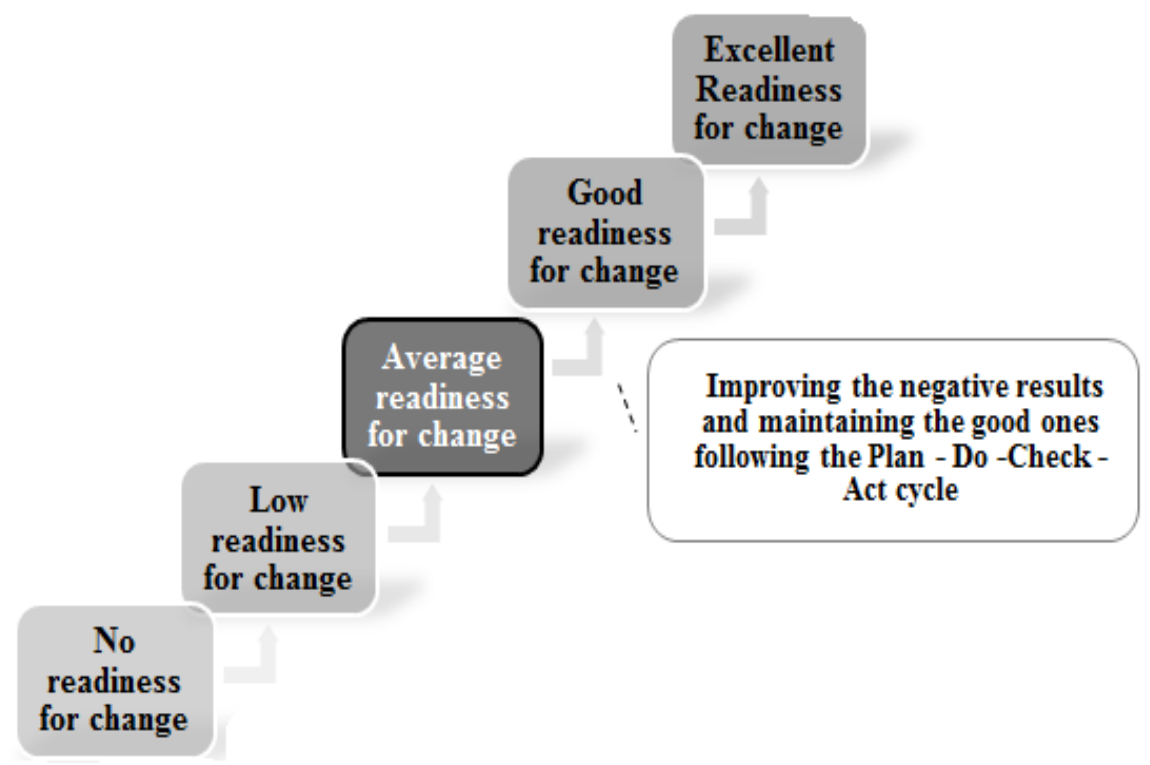

Figure 3. Change readiness level for the implementation of CSR within a Moroccan bank. 
Table 6. Criteria weights and evaluation values

\begin{tabular}{|c|c|c|c|c|c|c|c|c|c|c|}
\hline & & & & & & & Evalu & tion $r$ & ults & \\
\hline First level & $\begin{array}{c}\text { AHP } \\
\text { Weight }\end{array}$ & $\begin{array}{c}\text { AHP } \\
\text { Ranking }\end{array}$ & Second level & $\begin{array}{c}\text { Criteria } \\
\text { weights (AHP) }\end{array}$ & $\begin{array}{c}\text { AHP } \\
\text { Ranking }\end{array}$ & E \% & G \% & M \% & B \% & VB \% \\
\hline \multirow{6}{*}{ A 1: Change context } & \multirow{6}{*}{0.322} & \multirow{6}{*}{1} & A 11: Organizational politics & 0.037 & 33 & 10 & 40 & 40 & 10 & o \\
\hline & & & A 12: Past experience & 0.057 & 32 & 20 & 40 & 30 & 10 & O \\
\hline & & & A13: Policies and procedures & 0.095 & 27 & 20 & 40 & 30 & 10 & o \\
\hline & & & $\begin{array}{l}\text { A 14: Organizational climate and } \\
\text { culture }\end{array}$ & 0.425 & 5 & 10 & 40 & 30 & 10 & 10 \\
\hline & & & A 15: Cohesion & 0.129 & 23 & 20 & 40 & 30 & 10 & o \\
\hline & & & A16: Discrepancy & 0.256 & 14 & 20 & 50 & 20 & 10 & O \\
\hline \multirow{2}{*}{ A2: Change content } & \multirow{2}{*}{0.223} & \multirow{2}{*}{2} & A21: Organizational valence & 0.167 & 17 & 30 & 30 & 20 & 10 & 10 \\
\hline & & & A22: Appropriateness of the change & 0.833 & 1 & 40 & 30 & 20 & 10 & o \\
\hline \multirow{4}{*}{ A3: Structural factors } & \multirow{4}{*}{0.088} & \multirow{4}{*}{5} & A31: Knowledge & 0.060 & 30 & 10 & 30 & 50 & 10 & 0 \\
\hline & & & A32: Skills & 0.102 & 24 & 10 & 30 & 50 & 10 & $\mathrm{O}$ \\
\hline & & & A33: Ability alignment & 0.439 & 4 & 10 & 30 & 50 & 10 & O \\
\hline & & & $\begin{array}{l}\text { A34: Organizational resources and } \\
\text { structure }\end{array}$ & 0.399 & 7 & 20 & 20 & 50 & 10 & o \\
\hline \multirow{3}{*}{$\begin{array}{l}\text { A4: Change process } \\
\text { readiness }\end{array}$} & \multirow{3}{*}{0.153} & \multirow{3}{*}{3} & A41: Management support & 0.156 & 19 & 30 & 30 & 30 & 10 & o \\
\hline & & & A42: Attitudes of top management & 0.224 & 15 & 30 & 30 & 30 & 10 & $\mathrm{O}$ \\
\hline & & & A43: Participation & 0.620 & 2 & 20 & 40 & 30 & 10 & o \\
\hline \multirow{6}{*}{$\begin{array}{l}\text { A5: Change communication } \\
\text { readiness }\end{array}$} & \multirow{6}{*}{0.111} & \multirow{6}{*}{4} & $\begin{array}{l}\text { A51: Communication on } \\
\text { discrepancy }\end{array}$ & 0.153 & 20 & 10 & 30 & 50 & 10 & $\mathrm{O}$ \\
\hline & & & A52: Communication on efficacy & 0.100 & 26 & 0 & 10 & 40 & 30 & 20 \\
\hline & & & $\begin{array}{l}\text { A53: Communication on } \\
\text { appropriateness of change }\end{array}$ & 0.270 & 13 & 10 & 30 & 50 & 10 & $\mathrm{O}$ \\
\hline & & & $\begin{array}{l}\text { A54: Communication on principal } \\
\text { support }\end{array}$ & 0.344 & 9 & $\mathrm{O}$ & 30 & 30 & 20 & 20 \\
\hline & & & A55: Communication on valence & 0.075 & 28 & $\mathrm{O}$ & 30 & 30 & 20 & 20 \\
\hline & & & $\begin{array}{l}\text { A56: Quality of change } \\
\text { communication }\end{array}$ & 0.057 & 31 & 10 & 30 & 40 & 20 & o \\
\hline \multirow{3}{*}{ A6: Change agent attributes } & \multirow{3}{*}{0.051} & \multirow{3}{*}{6} & A61: Perceived credibility & 0.271 & 12 & 10 & 50 & 30 & 10 & o \\
\hline & & & A62: Trustworthiness & 0.162 & 18 & 20 & 30 & 40 & 10 & o \\
\hline & & & A63: Sincerity & 0.144 & 22 & 10 & 40 & 30 & 10 & 10 \\
\hline
\end{tabular}


International Journal of Management and Sustainability, 2022, 11(1): 1-20

\begin{tabular}{|c|c|c|c|c|c|c|c|c|c|c|}
\hline & & & A64: Expertise & 0.423 & 6 & 20 & 40 & 40 & $\mathrm{O}$ & $\mathrm{O}$ \\
\hline \multirow{3}{*}{$\begin{array}{l}\text { A7: Change recipient's } \\
\text { individual factors }\end{array}$} & \multirow{3}{*}{0.022} & \multirow{3}{*}{8} & A71: Values & 0.490 & 3 & 30 & 30 & 40 & 0 & $\mathrm{O}$ \\
\hline & & & A72: Self-efficacy & 0.198 & 16 & $\mathrm{O}$ & 20 & 50 & 20 & 10 \\
\hline & & & A73: Yield - personal valence & 0.312 & 11 & $\mathrm{O}$ & 30 & 40 & 30 & $\mathrm{O}$ \\
\hline \multirow{5}{*}{$\begin{array}{l}\text { A8: Change recipient's } \\
\text { organizational factors }\end{array}$} & \multirow{5}{*}{0.031} & \multirow{5}{*}{7} & A81: Vision for change & 0.355 & 8 & 10 & 50 & 20 & 20 & $\mathrm{O}$ \\
\hline & & & A82: Organizational commitment & 0.325 & 10 & 10 & 50 & 20 & 20 & $\mathrm{O}$ \\
\hline & & & A83: Trust in leadership & 0.101 & 25 & 0 & 40 & 30 & 30 & 0 \\
\hline & & & A84: Collective efficacy & 0.152 & 21 & $\mathrm{O}$ & 40 & 30 & 20 & 10 \\
\hline & & & A85: Social relationships & 0.068 & 29 & 10 & 40 & 30 & 10 & 10 \\
\hline
\end{tabular}

Table 7. First-grade FCEM results.

\begin{tabular}{|c|c|c|c|c|c|c|c|c|}
\hline & & \multicolumn{5}{|c|}{ Result $\mathrm{Bi}=\mathrm{Wi}^{*} \mathrm{Ri}$} & \multirow{2}{*}{ Obtained Level } & \multirow{2}{*}{ Maturity Interpretation } \\
\hline & & $\mathbf{E}$ & $\mathbf{G}$ & $\mathbf{M}$ & B & VB & & \\
\hline Change context & $\mathrm{B} 1$ & 0.154 & 0.4252 & 0.278 & 0.100 & 0.043 & Good & Good readiness for change \\
\hline Change content & $\mathrm{B} 2$ & 0.3833 & 0.300 & 0.200 & 0.100 & 0.017 & Excellent & Excellent readiness for change \\
\hline Structural factors & B3 & 0.1399 & 0.2601 & 0.5000 & 0.1000 & 0.0000 & Medium & Average readiness for change \\
\hline Change process readiness & $\mathrm{B} 4$ & 0.238 & 0.3620 & 0.300 & 0.100 & 0.000 & Good & Good readiness for change \\
\hline Change communication readiness & B5 & 0.048 & 0.280 & 0.4000 & 0.168 & 0.104 & Medium & Average readiness for change \\
\hline Change agent attributes & B6 & 0.159 & 0.4109 & 0.359 & 0.058 & 0.014 & Good & Good readiness for change \\
\hline Change recipient's individual factors & B7 & 0.147 & 0.280 & 0.4198 & 0.133 & 0.020 & Medium & Average readiness for change \\
\hline Change recipient's organizational factors & B8 & 0.075 & 0.4684 & 0.232 & 0.204 & 0.022 & Good & Good readiness for change \\
\hline
\end{tabular}




\section{DISCUSSION}

Before analyzing the obtained results, the suitability of the proposed method should also be discussed. In this regard, it was noted that using the Analytic Hierarchy Process to weigh the factors and sub-factors is practical because it allows the participants to express their opinions through pairwise comparisons; by using the linguistic variables provided in L. Saaty's scale, it becomes possible to take their subjectivity and uncertainty into consideration. This same advantage is also present when using the fuzzy comprehensive evaluation method since it relies on fuzzy logic to elicit and capture the experts' judgements and evaluations, thereby providing a mean to obtain detailed evaluation results per factor and per group of factors, making it easier to identify improvement areas by focusing improvement efforts on factors with low or medium evaluation results.

However, it is not an easy task to reach a consensus among the participants; the Delphi method is reliable in this regard but could be time-consuming as it depends on the participants' reactivity and responsiveness. Indeed, it requires the elaboration and synthesis of intermediate feedback reports to give back to experts, gathering their feedback and repeating the operation until the consensus is reached.

Concerning the use of a maturity model perspective, this offered the practical advantage of providing the decisionmakers with clear results as it situates the organization's change readiness maturity level on a spectrum.

Overall, the proposed methodology has allowed us to answer the defined research questions by measuring the bank's change readiness maturity level and identifying specific improvement areas based on the evaluation results, that will ensure and enhance proactive and supportive behaviors for change.

The following section will provide the analysis and discussion of the obtained results.

The obtained weights for the first level of the EIS show the importance given to the context (0.322) and content of the change (0.223), followed by change process readiness (0.153), and change communication readiness (0.111). After that we have structural factors (0.088), change agent attributes (0.051), the change recipient's organizational factors (0.031), and finally the change recipient's individual factors (0.022).

In the context category, the most significant factors proved to be the organizational climate and culture (0.425) and discrepancy (0.256). Organizational culture is considered important in the CSR literature (Kahreh, Mirmehdi, \& Eram, 2013). It promotes employee development (Chaudhary \& Akhouri, 2018) and raises awareness of CSR initiatives, leading to increased involvement (Brunton, Eweje, \& Taskin, 2017). Explaining and conveying the need for the change is crucial and ensures the discrepancy for CSR implementation.

In the content category, we have the change's appropriateness (0.833) and organizational valence (0.167). Ensuring the coherence between changes and their relevance to the company's context and strategy is recommended. Therefore, CSR programs should be implemented within the wider business strategy (Du, Bhattacharya, \& Sen, 2015; Martinez-Conesa, Soto-Acosta, \& Palacios-Manzano, 2017) in a holistic approach (Reverte et al., 2016). Concerning organizational valence, it is beneficial to emphasize the different benefits that the company will gain from CSR, as previously described

Within the process category, participation (Chaudhary \& Akhouri, 2018) and employee involvement are a critical success factor (Fuzi, Habidin, Hibadullah, Zamri, \& Desa, 2015) often referred to as CSR proximity. This entails making employees both co-producers and enactors of the CSR program (Du et al., 2015). Participation is followed by attitudes of top management (0.224) and management support (0.156). Indeed, top management commitment is critical to the success of CSR (Kahreh et al., 2013). Du et al. (2015) emphasizes the role of managers in raising CSR awareness and facilitating employee commitment and engagement; the latter point is also supported by Brunton et al. (2017).

Effective communication has its importance (Mory, Wirtz, \& Göttel, 2016) whether it is regarding the authentic and positive intentions of the company to contribute to the welfare of society (Chaudhary \& Akhouri, 2018), or the expected benefits for the purpose of raising employee engagement (Du et al., 2015), or especially aimed at internal stakeholders (Brunton et al., 2017). The weights attributed by the focus group placed communication on principal 
support (0.344) and communication on the appropriateness of the change (0.270) at the top. The obtained results are in line with the CSR literature.

Concerning structural factors, the top-weighted sub-factors are ability alignment (0.439) and organizational resources and structure (0.399).

For change agent attributes (0.051), referring to the project team, the most relevant factors are judged to be expertise (0.423) and perceived credibility (0.271).

Regarding the change recipient's organizational (0.031) and individual factors (0.022), vision (0.355) and organizational commitment (0.325) were attributed higher weights in the first category. The commitment factor is extensively evidenced in the literature (Brunton et al., 2017; Chaudhary \& Akhouri, 2018; Kahreh et al., 2013; Mory et al., 2016). For the second category, values (0.490) and yield - personal valence (0.312) were attributed higher weights. We also find efficacy to be an important factor in both the individual (0.198) and organizational categories (0.152). Indeed, self-efficacy has often been linked to the success of CSR programs (Chaudhary \& Akhouri, 2018).

The evaluation obtained from the AHP FCEM maturity model shows that the content of the project is perceived to be excellent, while the change context, process readiness, agents of change, and recipient's organizational attributes are deemed to be good, and the structural factors, change communication and recipient's individual attributes are perceived to be average and therefore require improvement. Globally the company's readiness is above average but still requires improvement to be good overall.

The obtained results were presented to the participants during a final work session, to share and discuss the results and work on the creation of an improvement roadmap. This session led to the formulation of the following recommendations: the establishment of a training plan to improve knowledge and skills, the clear definition and communication of roles and responsibilities for better ability alignment, the provision of management support for increased self-efficacy, financial and human resources forecasting to better plan organizational resources and structure, the development of a communication plan based on effective change messages (discrepancy, efficacy, appropriateness of the change, management support and valence) with feedback channels, and the development and diffusion of guides and charters that communicate the company's values.

To sum up, to achieve successful implementation of CSR, companies must understand their sphere of influence and their stakeholders' needs by utilizing formal communication channels and identifying and prioritizing core CSRrelated issues. The company's vision, mission statement, values and purpose should be congruent with their CSR strategy and their proclaimed commitments. A good CSR program results from a customized approach that is coproduced and implemented by all stakeholders. This entails the participation of all and ensures a strong commitment. It gives the approach more legitimacy and guarantees its sustainability, as significant time is needed to change behaviors. Transparency and communication (about the company's performance, CSR commitments and other CSR-related information) are key elements of a credible CSR program and in the fight against skepticism. The implementation of CSR within the company will sustainably transform individual and organizational behaviors and thus contribute to the welfare of society and the environment.

\section{CONCLUSION}

This study presents a change readiness evaluation framework based on a review of the previous literature on change readiness. It relies on a combination of the Analytic Hierarchy Process (AHP) and the Fuzzy Comprehensive Evaluation Method (FCEM) along with a maturity model perspective. The Delphi method was also used to reach a consensus among the participants. The proposed evaluation framework has several implications for practice; it allows the organization's change readiness maturity level to be defined and provides insights into areas that need further improvement to achieve a higher level of change readiness. In the case study on the implementation of a corporate social responsibility approach within a bank, it appears that the bank's change readiness maturity level is average and that further improvement efforts should be made in the area of structural factors, by ensuring the ability alignment 
of employees and the availability of organizational resources and structure, as well as in the area of communication, by defining a communication plan based on effective change messages with feedback channels. Other improvement areas include improving change recipients' individual attributes by ensuring management support and training plans for increased self-efficacy, as well as the use of guides and charters to communicate the company's values. Another potential use of this evaluation framework is the study of group differences in terms of change readiness. We recommend that future research focuses on conducting longitudinal studies and exploring other change readiness factors (cognitive, affective, etc.) to enrich the framework and study its generalizability.

Funding: This study received no specific financial support.

Competing Interests: The authors declare that they have no competing interests.

Authors' Contributions: Both authors contributed equally to the conception and design of the study.

\section{REFERENCES}

Armenakis, A. A., Bernerth, J. B., Pitts, J. P., \& Walker, H. J. (2007). Organizational change recipients' beliefs scale: Development of an assessment instrument. The Journal of Applied Behavioral Science, 43(4), 481-505. Available at: https://doi.org/10.1177/0021886307303654.

Armenakis, A. A., \& Fredenberger, W. B. (1997). Organizational change readiness practices of business turnaround change agents. Knowledge and Process Management, 4(3), 143-152. Available at: https://doi.org/10.1002/(sici)10991441(199709)4:3\%3C143::aid-kpm93\%3E3.0.co;2-7.

Armenakis, A. A., Harris, S. G., \& Mossholder, K. W. (1993). Creating readiness for organizational change. Human Relations, 46(6), 681-703. Available at: https://doi.org/10.1177/001872679304600601.

Armenakis., A. A., \& Stanley, G. H. (2002). Crafting a change message to create transformational readiness. Journal of Organizational Change Management, 15(2), 169-183. Available at: https://doi.org/10.1108/09534810210423080.

Backer, T. E. (1995). Assessing and enhancing readiness for change: Implications for technology transfer. NIDA Research Monograph (Vol. 155, pp. 21-41). Rockville, MD: National Institute on Drug Abuse.

Bernerth, J. (2004). Expanding our understanding of the change message. Human Resource Development Review, 3(1), 36-52. Available at: https://doi.org/10.1177/1534484303261230.

Bouckenooghe, D., Devos, G., \& Van den Broeck, H. (2009). Organizational change questionnaire-climate of change, processes, and readiness: Development of a new instrument. The Journal of Psychology, 143(6), 559-599. Available at: https://doi.org/10.1080/00223980903218216.

Bowen, H. R. (1953). Social responsibilities of the businessman. New York: Harper \& Row.

Breitbarth, T., \& Rieth, L. (2012). Strategy, stakeholder, structure: Key drivers for successful CSR integration in German professional football. Contextualising Research in Sport: An International Perspective, In C. Anangnostopoulos (Eds.) (pp. 45-63). Athens: ATINER.

Brunton, M., Eweje, G., \& Taskin, N. (2017). Communicating corporate social responsibility to internal stakeholders: Walking the walk or just talking the talk? Business Strategy and the Environment, 26(1), 31-48. Available at: https://doi.org/10.1002/bse.1889.

Carroll, A. B. (2008). A history of corporate social responsibility: Concepts and practices. Crane, A., McWilliams, A., Matten, D., Siegel, D., S.(eds.), The Oxford Handbook of Corporate Social Responsibility. New York: Oxford University Press Inc.

Chaudhary, R., \& Akhouri, A. (2018). Linking corporate social responsibility attributions and creativity: Modeling work engagement as a mediator. Journal of Cleaner Production, 190, 809-821. Available at: https://doi.org/10.1016/j.jclepro.2018.04.187.

Cinite, I., Duxbury, L. E., \& Higgins, C. (2009). Measurement of perceived organizational readiness for change in the public sector. British Journal of Management, 20(2), 265-277. Available at: https://doi.org/10.1111/j.1467-8551.2008.00582.x.

Combe, M. (2014). Change readiness: Focusing change management where it counts. PMI White Paper, Newtown Square, PA: Project Management Institute. 
Cunningham, C. E., Woodward, C. A., Shannon, H. S., MacIntosh, J., Lendrum, B., Rosenbloom, D., \& Brown, J. (2002). Readiness for organizational change: A longitudinal study of workplace, psychological and behavioural correlates. Journal of Occupational and Organizational Psychology, 75(4), 377-392. Available at: https://doi.org/10.1348/096317902321119637.

Dalkey, N., \& Helmer, O. (1963). An experimental application of the Delphi method to the use of experts. Management Science, 9(3), 458-467. Available at: https://doi.org/10.1287/mnsc.9.3.458.

Dievernich, F. E. (2015). The rediscovery of the human being and the future of change management. In Change Management and the Human Factor (pp. 9-18). Cham: Springer.

Du, S., Bhattacharya, C., \& Sen, S. (2015). Corporate social responsibility, multi-faceted job-products, and employee outcomes. Journal of Business Ethics, 131(2), 319-335. Available at: https://doi.org/10.1007/s 10551-014-2286-5.

Fuzi, N. M., Habidin, N. F., Hibadullah, S. N., Zamri, F. I. M., \& Desa, A. F. N. C. (2015). Critical success factors of corporate social responsibility practices for the Malaysian automotive industry. International Journal of Critical Accounting, 7(2), 142-156. Available at: https://doi.org/10.1504/ijca.2015.069950.

Gagnon, M.-P., Attieh, R., Ghandour, E. K., Legare, F., Ouimet, M., Estabrooks, C. A., \& Grimshaw, J. (2014). A systematic review of instruments to assess organizational readiness for knowledge translation in health care. PloS One, 9(12), e114338. Available at: https://doi.org/10.1371/journal.pone.0114338.

Gond, J. P., \& Igalens, J. (2008). Corporate social responsibility. Salt Lake: University Presses of France.

Halpern, N., Mwesiumo, D., Suau-Sanchez, P., Budd, T., \& Bråthen, S. (2021). Ready for digital transformation? The effect of organisational readiness, innovation, airport size and ownership on digital change at airports. Journal of Air Transport Management, 90, 101949. Available at: https://doi.org/10.1016/j.jairtraman.2020.101949.

Helfrich, C. D., Li, Y.-F., Sharp, N. D., \& Sales, A. E. (2009). Organizational readiness to change assessment (ORCA): Development of an instrument based on the promoting action on research in health services (PARIHS) framework. Implementation Science, 4(1), 1-13. Available at: https://doi.org/10.1186/1748-5908-4-38.

Holt, D. T., Armenakis, A. A., Feild, H. S., \& Harris, S. G. (2007). Readiness for organizational change: The systematic development of a scale. The Journal of Applied Behavioral Science, 43(2), 232-255.

Holt, D. T., Helfrich, C. D., Hall, C. G., \& Weiner, B. J. (2010). Are you ready? How health professionals can comprehensively conceptualize readiness for change. Journal of General Internal Medicine, 25(S1), 50-55. Available at: https://doi.org/10.1007/s11606-009-1112-8.

Holt, D. T., \& Vardaman, J. M. (2013). Toward a comprehensive understanding of readiness for change: The case for an expanded conceptualization. Journal of Change Management, 13(1), 9-18. Available at: https://doi.org/10.1080/14697017.2013.768426.

Hujainah, F., Bakar, R. B. A., Abdulgabber, M. A., \& Zamli, K. Z. (2018). Software requirements prioritisation: A systematic literature review on significance, stakeholders, techniques and challenges. IEEE Access, 6, 71497-71523. Available at: https://doi.org/10.1109/access.2018.2881755.

Jonikas, D. (2012). Value creation through CSR at stakeholders level. Economics and Management, 17(2), 693-698. Available at: https://doi.org/10.5755/jo1.em.17.2.2200.

Kahreh, M. S., Mirmehdi, S. M., \& Eram, A. (2013). Investigating the critical success factors of corporate social responsibility implementation: Evidence from the Iranian banking sector. Corporate Governance: International Journal of Business in Society, 13(2), 184-197. Available at: https://doi.org/10.1108/14720701311316661.

Kang, J.-S., Chiang, C.-F., Huangthanapan, K., \& Downing, S. (2015). Corporate social responsibility and sustainability balanced scorecard: The case study of family-owned hotels. International Journal of Hospitality Management, 48, 124-134. Available at: https://doi.org/10.1016/j.ijhm.2015.05.001.

Kotler, P., \& Lee, N. (2005). Corporate social responsibility: Doing the most good for your company and your cause. Hoboken, NJ: John Wiley \& Sons, Inc.

Kotter, J. (2007). Leading change: Why transformation efforts fail. Harvard Business Review, 86, 97-103.

Kramer, M. R., \& Porter, M. (2011). Creating shared value (Vol. 17): FSG. 
Lehman, W. E., Greener, J. M., \& Simpson, D. D. (2002). Assessing organizational readiness for change. Journal of Substance Abuse Treatment, 22(4), 197-209.

Madsen, S. R., Miller, D., \& John, C. R. (2005). Readiness for organizational change: Do organizational commitment and social relationships in the workplace make a difference? Human Resource Development Quarterly, 16(2), 213-234. Available at: https://doi.org/10.1002/hrdq.1134.

Martinez-Conesa, I., Soto-Acosta, P., \& Palacios-Manzano, M. (2017). Corporate social responsibility and its effect on innovation and firm performance: An empirical research in SMEs. Journal of Cleaner Production, 142, 2374-2383. Available at: https://doi.org/10.1016/j.jclepro.2016.11.038.

Mory, L., Wirtz, B. W., \& Göttel, V. (2016). Factors of internal corporate social responsibility and the effect on organizational commitment. The International Journal of Human Resource Management, 27(13), 1393-1425.

Murphy, P. E. (1978). An evolution: Corporate social responsiveness. University of Michigan Business Review, 30(6), 19-25.

Németh, B., Molnár, A., Bozóki, S., Wijaya, K., Inotai, A., Campbell, J. D., \& Kaló, Z. (2019). Comparison of weighting methods used in multicriteria decision analysis frameworks in healthcare with focus on low-and middle-income countries. Journal of Comparative Effectiveness Research, 8(4), 195-204. Available at: https://doi.org/10.2217/cer-2018-0102.

Rafferty, A. E., Jimmieson, N. L., \& Armenakis, A. A. (2013). Change readiness: A multilevel review. Journal of Management, 39(1), 110-135. Available at: https://doi.org/10.1177/0149206312457417.

Reverte, C., Gomez-Melero, E., \& Cegarra-Navarro, J. G. (2016). The influence of corporate social responsibility practices on organizational performance: Evidence from eco-responsible Spanish firms. Journal of Cleaner Production, 112, $2870-2884$. Available at: https://doi.org/10.1016/j.jclepro.2015.09.128.

Saaty, T. L. (1990). How to make a decision: The analytic hierarchy process. European Journal of Operational Research, 48(1), 9-26. Available at: https://doi.org/10.1016/0377-2217(90)90057-i.

Saeidi, S. P., Sofian, S., Saeidi, P., Saeidi, S. P., \& Saaeidi, S. A. (2015). How does corporate social responsibility contribute to firm financial performance? The mediating role of competitive advantage, reputation, and customer satisfaction. Journal of Business Research, 68(2), 341-350. Available at: https://doi.org/10.1016/j.jbusres.2014.06.024.

Shea, C. M., Jacobs, S. R., Esserman, D. A., Bruce, K., \& Weiner, B. J. (2014). Organizational readiness for implementing change: A psychometric assessment of a new measure. Implementation Science, 9(1), 1-15. Available at: https://doi.org/10.1186/1748-5908-9-7.

Smith, I. (2005). Achieving readiness for organisational change. Library Management, 26(6-7), 408-412. Available at: https://doi.org/10.1108/01435120510623764.

Stevens, G. W. (2013). Toward a process-based approach of conceptualizing change readiness. The Journal of Applied Behavioral Science, 49(3), 333-360. Available at: https://doi.org/10.1177/0021886313475479.

Turner, A. N. (1982). Consulting is more than giving advice. Harvard Business Review, 60(5), 120-129.

Vakola, M. (2013). Multilevel readiness to organizational change: A conceptual approach. Journal of Change Management, 13(1), 96109. Available at: https://doi.org/10.1080/14697017.2013.768436.

Weiner, B. J. (2009). A theory of organizational readiness for change. Implementation Science, 4(1), 1-9. Available at: https://doi.org/10.1186/1748-5908-4-67.

Weiner, B. J., Amick, H., \& Lee, S.-Y. D. (2008). Conceptualization and measurement of organizational readiness for change: A review of the literature in health services research and other fields. Medical Care Research and Reviere, 65(4), 379-436. Available at: https://doi.org/10.1177/1077558708317802.

Weiner, B. J., Clary, A. S., Klaman, S. L., Turner, K., \& Alishahi-Tabriz, A. (2020). Organizational readiness for change: What we know, what we think we know, and what we need to know. Implementation Science, 3, 101-144. Available at: https://doi.org/10.1007/978-3-030-03874-8_5.

Yin, J., \& Jamali, D. (2016). Strategic corporate social responsibility of multinational companies subsidiaries in emerging markets: Evidence from China. Long Range Planning, 49(5), 541-558. Available at: https://doi.org/10.1016/j.lrp.2015.12.024. 
Zhu, B., \& Dewancker, B. (2021). A case study on the suitability of STARS for green campus in China. Evaluation and Program Planning, 84, 101893. Available at: https://doi.org/10.1016/j.evalprogplan.2020.101893.

Zollo, M., Minoja, M., Casanova, L., Hockerts, K., Neergaard, P., Schneider, S., \& Tencati, A. (2009). Towards an internal change management perspective of CSR: Evidence from project RESPONSE on the sources of cognitive alignment between managers and their stakeholders, and their implications for social performance. Corporate Governance: International Journal of Business in Society, 9(4), 355-372. Available at: https://doi.org/10.1 108/14720700910984918.

Appendix A. Judgement matrices.

Level 1. Matrix

\begin{tabular}{l|c|c|c|c|c|c|c|c}
\hline & A1 & A2 & A3 & A4 & A5 & A6 & A7 & A8 \\
\hline A1 & 1 & 2 & 5 & 3 & 4 & 6 & 8 & 7 \\
\hline A2 & $1 / 2$ & 1 & 4 & 2 & 3 & 5 & 7 & 6 \\
\hline A3 & $1 / 5$ & $1 / 4$ & 1 & $1 / 3$ & $1 / 2$ & 2 & 7 & 5 \\
\hline A4 & $1 / 3$ & $1 / 2$ & 3 & 1 & 2 & 4 & 6 & 5 \\
\hline A5 & $1 / 4$ & $1 / 3$ & 2 & $1 / 2$ & 1 & 3 & 6 & 5 \\
\hline A6 & $1 / 6$ & $1 / 5$ & $1 / 2$ & $1 / 4$ & $1 / 3$ & 1 & 4 & 2 \\
\hline A7 & $1 / 8$ & $1 / 7$ & $1 / 7$ & $1 / 6$ & $1 / 6$ & $1 / 4$ & 1 & $1 / 2$ \\
\hline A8 & $1 / 7$ & $1 / 6$ & $1 / 5$ & $1 / 5$ & $1 / 5$ & $1 / 2$ & 2 & 1 \\
\hline
\end{tabular}

With: $\Lambda \max =8.473 \quad \mathrm{CI}=0.067 \quad \mathrm{CR}=0.047$

Level 2. Matrices.

Change context

\begin{tabular}{c|c|c|c|c|c|c}
\hline & A11 & A12 & A13 & A14 & A15 & A16 \\
\hline A11 & 1 & $1 / 2$ & $1 / 3$ & $1 / 8$ & $1 / 3$ & $1 / 7$ \\
\hline A12 & 2 & 1 & $1 / 2$ & $1 / 6$ & $1 / 3$ & $1 / 5$ \\
\hline A13 & 3 & 2 & 1 & $1 / 4$ & $1 / 2$ & $1 / 3$ \\
\hline A14 & 8 & 6 & 4 & 1 & 4 & 3 \\
\hline A15 & 3 & 3 & 2 & $1 / 4$ & 1 & $1 / 3$ \\
\hline A16 & 7 & 5 & 3 & $1 / 3$ & 3 & 1 \\
\hline
\end{tabular}

\section{Structural factors}

\begin{tabular}{l|c|c|c|c}
\hline & A31 & A32 & A33 & A34 \\
\hline A31 & 1 & $1 / 2$ & $1 / 7$ & $1 / 6$ \\
\hline A32 & 2 & 1 & $1 / 5$ & $1 / 4$ \\
\hline A33 & 7 & 5 & 1 & 1 \\
\hline A34 & 6 & 4 & 1 & 1 \\
\hline
\end{tabular}

$\Lambda \max =4.017 \mathrm{CI}=0.005 \mathrm{CR}=0.006$.

Change communication readiness

\begin{tabular}{c|c|c|c|c|c|c}
\hline & A51 & A52 & A53 & A54 & A55 & A56 \\
\hline A51 & 1 & 2 & $1 / 3$ & $1 / 3$ & 4 & 3 \\
\hline A52 & $1 / 2$ & 1 & $1 / 4$ & $1 / 4$ & 3 & 2 \\
\hline A53 & 3 & 4 & 1 & $1 / 2$ & 5 & 3 \\
\hline A54 & 3 & 4 & 2 & 1 & 4 & 4 \\
\hline A55 & $1 / 4$ & $1 / 3$ & $1 / 5$ & $1 / 4$ & 1 & 3 \\
\hline A56 & $1 / 3$ & $1 / 2$ & $1 / 3$ & $1 / 4$ & $1 / 3$ & 1 \\
\hline
\end{tabular}

$\Lambda \max =6.542 \mathrm{CI}=0.108 \mathrm{CR}=0.087$
Change content

\begin{tabular}{l|c|c}
\hline & A21 & A22 \\
\hline $\mathrm{A} 21$ & 1 & $1 / 5$ \\
\hline $\mathrm{A} 22$ & 5 & \\
\hline \multicolumn{2}{l}{$\Lambda \max =2 \mathrm{CI}=0 \mathrm{CR}=0$}
\end{tabular}

\section{Change process readiness}

\begin{tabular}{l|c|c|c}
\hline & A41 & A42 & A43 \\
\hline $\mathrm{A} 41$ & 1 & $1 / 2$ & $1 / 3$ \\
\hline $\mathrm{A} 42$ & 2 & 1 & $1 / 4$ \\
\hline $\mathrm{A} 43$ & 3 & 4 & 1 \\
\hline \multicolumn{4}{l}{$\Lambda \max =3.109 \mathrm{CI}=0.054 \mathrm{CR}=0.094$}
\end{tabular}

\section{Change agent attributes}

\begin{tabular}{l|c|c|c|c}
\hline & A61 & A62 & A63 & A64 \\
\hline A61 & 1 & 2 & 2 & $1 / 2$ \\
\hline A62 & $1 / 2$ & 1 & 1 & $1 / 2$ \\
\hline A63 & $1 / 2$ & 1 & 1 & $1 / 3$ \\
\hline A64 & 2 & 2 & 3 & 1 \\
\hline \multicolumn{4}{l}{$\max =4.045 \mathrm{CI}=0.015 \mathrm{CR}=0.016$}
\end{tabular}


International Journal of Management and Sustainability, 2022, 11(1): 1-20

Change recipient individual factors

\begin{tabular}{l|c|c|c}
\hline & A71 & A72 & A73 \\
\hline A71 & 1 & 2 & 2 \\
\hline A72 & $1 / 2$ & 1 & $1 / 2$ \\
\hline A73 & $1 / 2$ & 2 & 1 \\
\hline
\end{tabular}

$\Lambda \max =3.053 \mathrm{CI}=0.026 \mathrm{CR}=0.046$
Change recipient organizational factors

\begin{tabular}{c|c|c|c|c|c}
\hline & A81 & A82 & A83 & A84 & A85 \\
\hline A81 & 1 & 2 & 3 & 2 & 4 \\
\hline A82 & $1 / 2$ & 1 & 4 & 3 & 5 \\
\hline A83 & $1 / 3$ & $1 / 4$ & 1 & $1 / 2$ & 2 \\
\hline A84 & $1 / 2$ & $1 / 3$ & 2 & 1 & 2 \\
\hline A85 & $1 / 4$ & $1 / 5$ & $1 / 2$ & $1 / 2$ & 1 \\
\hline
\end{tabular}

$\Lambda \max =5.169 \mathrm{CI}=0.042 \mathrm{CR}=0.037$

Views and opinions expressed in this article are the views and opinions of the author(s), International Journal of Management and Sustainability shall not be responsible or answerable for any loss, damage or liability etc. caused in relation to/arising out of the use of the content. 